\title{
The potential of mesenchymal stem cells in the management of radiation enteropathy
}

\author{
P-Y Chang ${ }^{1,2}, Y-Q Q^{1}{ }^{1}, J$ Wang ${ }^{2}$ and L-H Dong ${ }^{*, 1}$
}

\begin{abstract}
Although radiotherapy is effective in managing abdominal and pelvic malignant tumors, radiation enteropathy is still unavoidable. This disease severely affects the quality of life of cancer patients due to some refractory lesions, such as intestinal ischemia, mucositis, ulcer, necrosis or even perforation. Current drugs or prevailing therapies are committed to alleviating the symptoms induced by above lesions. But the efficacies achieved by these interventions are still not satisfactory, because the milieus for tissue regeneration are not distinctly improved. In recent years, regenerative therapy for radiation enteropathy by using mesenchymal stem cells is of public interests. Relevant results of preclinical and clinical studies suggest that this regenerative therapy will become an attractive tool in managing radiation enteropathy, because mesenchymal stem cells exhibit their proregenerative potentials for healing the injuries in both epithelium and endothelium, minimizing inflammation and protecting irradiated intestine against fibrogenesis through activating intrinsic repair actions. In spite of these encouraging results, whether mesenchymal stem cells promote tumor growth is still an issue of debate. On this basis, we will discuss the advances in anticancer therapy by using mesenchymal stem cells in this review after analyzing the pathogenesis of radiation enteropathy, introducing the advances in managing radiation enteropathy using regenerative therapy and exploring the putative actions by which mesenchymal stem cells repair intestinal injuries. At last, insights gained from the potential risks of mesenchymal stem cell-based therapy for radiation enteropathy patients may provide clinicians with an improved awareness in carrying out their studies.
\end{abstract}

Cell Death and Disease (2015) 6, e1840; doi:10.1038/cddis.2015.189; published online 6 August 2015

\section{Facts}

- Radiation enteropathy severely affected the quality of life of cancer patients nowadays.

- Preclinical data suggest the pro-regenerative effects of mesenchymal stem cells on irradiated intestine.

- Epinal case report reveals the specific effectiveness of mesenchymal stem cells in managing pelvic radiotherapyinduced lesions in rectum and bladder lesions.

\section{Open Questions}

- Due to most of radiation enteropathy patients are cancer survivors, is really that mesenchymal stem cells will initiate or promote their tumor growth?

- How to carry out a clinical trial for evaluating the therapeutic potentials of mesenchymal stem cells for radiation enteropathy?

- Will the mesenchymal stem cell-based therapy be an attractive tool for clinicians in managing radiation enteropathy patients in the future?
Radiotherapy is powerful in treating malignant tumors. According to the published data, at least $50 \%$ of cancer patients need radiotherapy during their treatment course, and approximately $25 \%$ of solid tumors undergo complete remission after radiotherapy. ${ }^{1}$ However, damage to healthy tissue within the radiation field remains unavoidable. For abdominopelvic radiotherapy, the intestine is defined as an organ at risk (OAR). Herein, small intestine commonly presents acute injuries due to its high $\alpha / \beta$ ratio of $>10$ Gy according to linear-quadratic (L-Q) model. Besides, the estimated $\alpha / \beta$ ratio in rectum varies between 4.8 Gy and $5.4 \mathrm{~Gy}$, commonly allowing for grade $\geq 2$ toxicity happening. ${ }^{2,3}$ Radiation-induced intestinal injuries/ toxicities are known as radiation enteropathy $(R E)$, which can be classified into two phases. Early RE commonly occurs within 3 months of radiotherapy, with an incidence of $\sim 50 \% .{ }^{4}$ Late RE can be observed from 1 to 20 years post radiotherapy, with the incidence of $2-20 \% .^{5,6}$ Several factors are involved in the development of late RE, including progressive cell loss and vascular obliteration in irradiated intestine, which will result in emergent or even fatal complications, such as obstruction, perforation, intestinal necrosis or acute hemorrhage. ${ }^{6,7}$

\footnotetext{
${ }^{1}$ Department of Radiation Oncology, The First Bethune Hospital of Jilin University, Changchun 130021, China and ${ }^{2}$ Electrochemical State Key Laboratory, Changchun Institute of Applied Chemistry Academy of Science, Changchun 130021, China

*Corresponding author: L-H Dong, Department of Radiation Oncology, The First Bethune Hospital of Jilin University, Changchun 130021, China. Tel: +86 15843073216; Fax: +86 0431 88782468; E-mail: drlhdong@163.com

Abbreviations: CBC, crypt base columnar; CGRP, calcitonin gene-related peptide; DC, dendritic cell; DSB, double-strand break; ECM, extracellular matrix; FI, fecal inconvenience; GVHD, graft versus host disease; HO-1, heme oxygenase-1; IBD, inflammatory bowel disease; LT, leukotriene; RE, radiation enteropathy; SLE, systemic lupus erythematosus; TLR, toll-like receptor; MMP, matrix metalloproteinase; MPO, myeloperoxidase; MSC, mesenchymal stem cell; MSD, manganese superoxide dismutase; NE, neutropenic enterocolitis; NF- $\mathrm{B}$, nuclear factor-kappa B; NOD-2, nucleotide-binding oligomerization domain-containing protein 2; OAR, organ at risk; TIMP, tissue inhibitor of metalloproteinase; Treg, regulatory T cell; vWF, von Willebrand factor

Received 19.3.15; revised 02.6.15; accepted 08.6.15; Edited by D Aberdam
} 
Current clinical interventions for early RE mainly aim to relieve abdominal pain and diarrhea through spasmolysis and anti-edema drugs, maintaining electrolyte balance through conditional nutrient supplementation and alleviating inflammation or infection using antioxidants, glucocorticoids or antibiotics. ${ }^{8}$ For late RE, lesioned intestine can be managed merely by surgery. ${ }^{8}$ However, resection of diseased intestine appears to be not very effective, because the fibrogenesis in irradiated intestine could not be inhibited. Additionally, intestinal adhesion following surgery and dystrophia induced by removing a large portion of intestine adversely affect patient quality of life. ${ }^{9}$ In recent years, the outcome from clinical studies exhibited the effectiveness of Pentoxifylline-Vitamin E in preventing intestinal fibrosis. ${ }^{10,11}$ Meanwhile, several preclinical studies proposed some available agents for managing late RE, including ROCK inhibitor (Y-27632), ${ }^{12}$ Pravastatin $^{13}$ and Simvastatin. ${ }^{14}$ In addition to developing potential drugs, several preclinical studies were carried out for evaluating the therapeutic potentials of mesenchymal stem cells (MSCs) for RE.

MSCs, a population of undifferentiated cells deriving from early ectoderm and can be harvested from various tissues and organs. ${ }^{15} \mathrm{MSC}$ can secret various types of growth factors, immune mediators and anti-fibrotic effectors, which are potent in mediating tissue regeneration. ${ }^{16-18}$ And several clinical trials revealed the immunomodulatory benefits of MSCs in treating graft versus host disease (GVHD), inflammatory bowel disease (IBD), systemic lupus erythematosus (SLE) and arthritis. ${ }^{19-22}$ Moreover, four patients, suffering from pelvic radiotherapy-induced injuries in rectum and in bladder, were successfully treated in Epinal Medical Center by using MSCs. ${ }^{6,23}$ The effectiveness of MSCs lies in reducing abdominal pain, stanching rectal hemorrhage and healing fistula. ${ }^{23}$ On this basis, we propose that managing RE patients by using MSCs will be an attractive therapeutic approach in the future.

In this review, we will build on evidence of an effect of MSCs on irradiated intestine by discussing the actions behind this effect, together with evidence relating to advances in anticancer therapy by using MSCs, to suggest the feasibility of

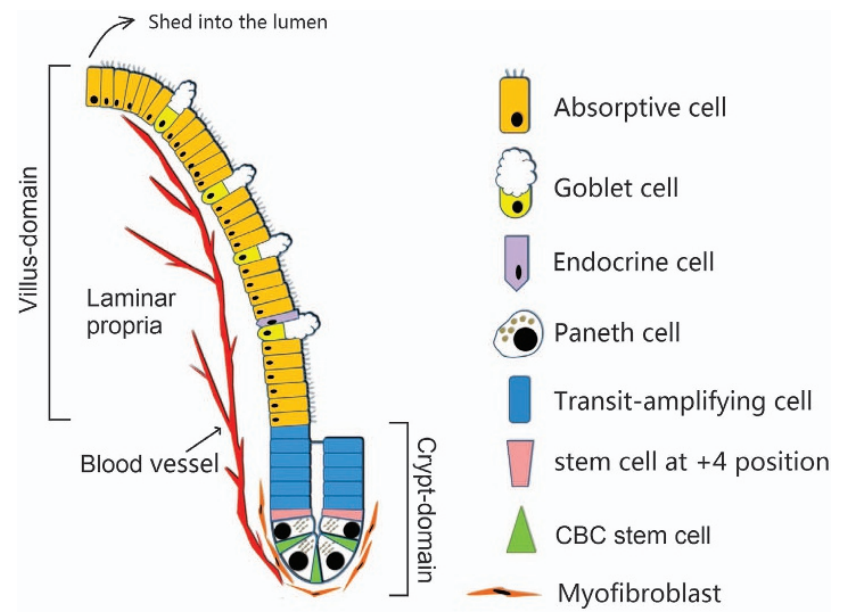

Figure 1 The structure of villus-crypt axis. This figure shows the homeostasis of intestinal epithelium regulating by $\mathrm{CBC}$ stem cells
MSCs in treating cancer patients with RE. At last, we will introduce the future efforts into carrying out MSC-related clinical trials for managing RE.

\section{Potential Factors Involved in Pathogenesis of RE}

Refractory lesions in the irradiated intestine develop through a lengthy process comprising multiple steps and contributory factors, although the mechanisms involving in RE pathogenesis remain unclear. Radiation-induced injuries refer to the histopathological changes in the epithelium and endothelium, where the oxidative stress and extended inflammation played a predominant role in leading to lesions, including ischemia, ulcer, necrosis or fibrosis. ${ }^{24,25}$ In this section, current understanding on the pathogenesis of RE will be shared.

Epithelial event: Intestinal stem cell injury-induced de-epithelialization. The intestinal epithelium has a rapid self-renewal capacity, with a complete turnover time of $\sim 96 \mathrm{~h}$ due to rapid cycling of cells within the crypts of Liberkühn. ${ }^{26}$ The crypt base columnar (CBC) stem cells are responsible for maintaining homeostasis of intestinal epithelium by their producing progeny: transit-amplifying cells, which are committed into mature epithelial cells after 4-5 divisions (Figure 1). ${ }^{27,28}$

The CBC stem cells are radiosensitive. ${ }^{29}$ It was reported that irradiation doses of at least $0.01 \mathrm{~Gy}$ are sufficient to result in apoptosis in $10 \%$ of CBC stem cells. ${ }^{30}$ The pro-apoptotic effects of ionizing irradiation on $\mathrm{CBC}$ stem cells are dependent on their cell-cycle stage. ${ }^{29}$ lonizing irradiation will cause more DNA double-strand breaks (DSB) in G2/M phase than in G1/S phase. ${ }^{31}$ The average dividing time of $C B C$ cells is reported to be $21.5 \mathrm{~h}$, which classifies them as rapid cycling and radiosensitive cells thereby. ${ }^{32}$

Recent evidence suggested that the CBC stem cells are indispensable for epithelial regeneration upon being irradiated. ${ }^{33}$ If the intestine receives the doses between 6 Gy and $12 \mathrm{~Gy}, \mathrm{CBC}$ stem cells can be replenished by another pool of intestinal stem cells at the 4+ position of crypts. ${ }^{34,35}$ Yet, if the irradiation doses are higher than $12 \mathrm{~Gy}$, the CBC stem cells will rapidly die along with subsequent depletion of Paneth cells, who form the niches of CBC stem cells. ${ }^{33,36}$ Together with the following processes, such as vascular damageinduced ischemia, oxidative stress and extended inflammation in irradiated sites, the milieus feeding CBC stem cells are further deteriorated, which even results in crypt death. ${ }^{37}$ Ultimately, the barrier function of epithelium is lost thereby (Figure 2).

Vascular event: endothelial injury-induced ischemia. The endothelial cells are primary targets of ionizing irradiation, and the apoptosis of endothelial cells accounts for the severity of lesions within irradiated intestine. ${ }^{38,39}$ Evidence lie in that during the first $4 \mathrm{~h}$ after lethal irradiation, the apoptotic cells, most of which are positive for CD31, are mainly located in the laminar propria of the villi rather than the epithelial layer. ${ }^{40}$ However, at $10 \mathrm{~h}$ post irradiation, numerous apoptotic cells are diffusely located in the epithelial layer from villi to crypt compartments rather than the laminar propira. ${ }^{40}$ This switch of apoptosis from endothelial cells to epithelial cells 

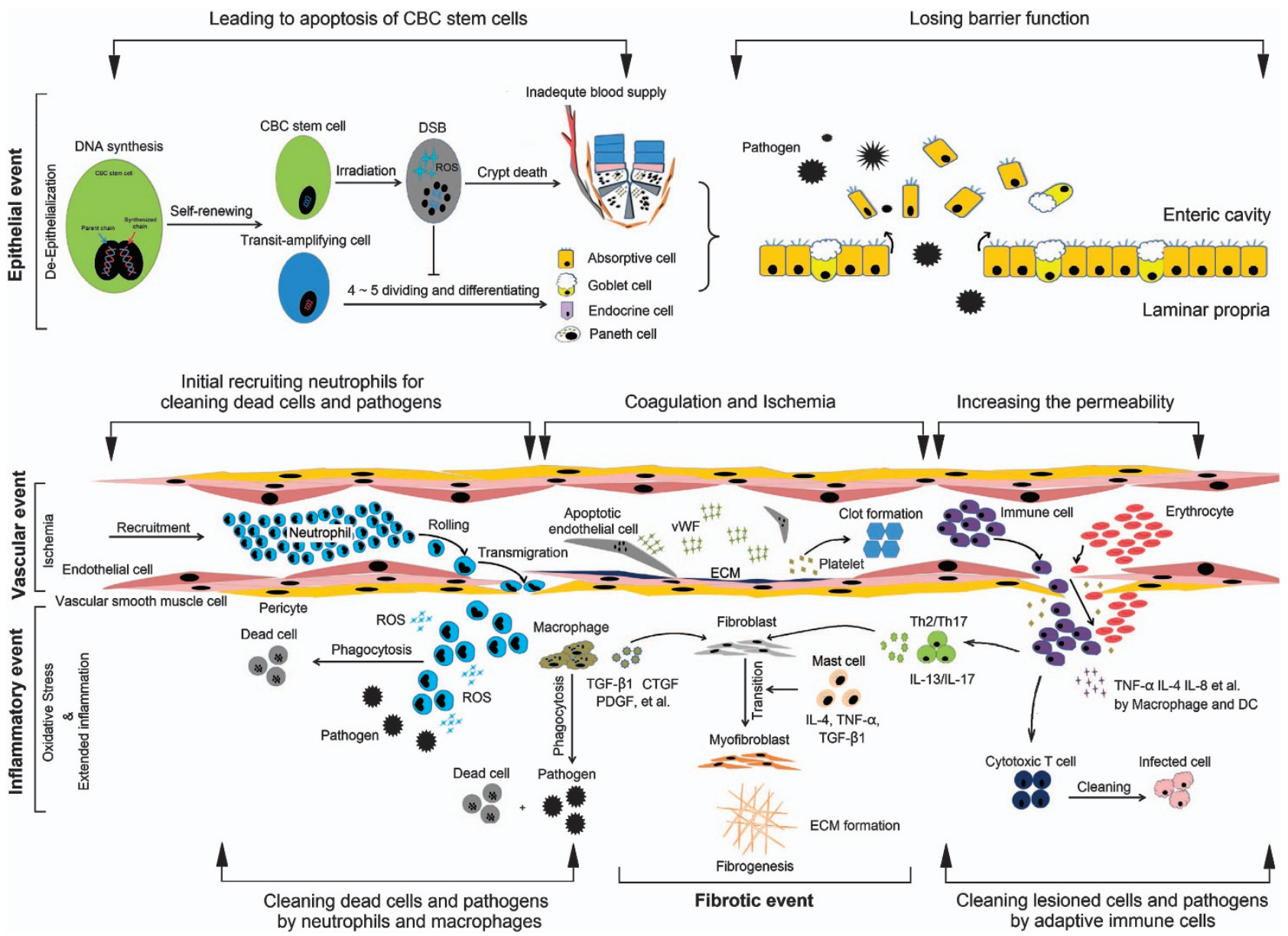

Figure 2 The pathogenesis of radiation enteropathy. Four events are involved in the pathogenesis of radiation enteropathy, including de-epithelization, ischemia, oxidative stress and fibrogenesis

indicates that injuries in irradiated intestinal cells are first occurred in endothelium. ${ }^{39,40}$

After endothelial injury occurring, sub-endothelial extracellular matrix (ECM) components are exposed to platelets, which initiate hemostasis mechanisms by forming clots. ${ }^{41}$ The coagulation cascade is hyperactivated by excessive secretion of von Willebrand factor (vWF) from injured endothelial cells, which results in vascular occlusion ultimately. ${ }^{42}$ Then, vascular permeability will be increased, which leads to hyperemia or hemorrhage within injured sites. ${ }^{43}$ As a result, the irradiated intestine has a poor blood supply (Figure 2).

Inflammatory event: increasing oxidative stress and extending inflammation. The chemical reactions that reduce cell viability in irradiated tissues have been identified as excessive production of ROS, such as superoxide radicals and hydrogen peroxide, which derive from intracellular water oxidized by radiation energy and from mitochondria. ${ }^{44,45}$ Under this condition, ROS can activate the signaling pathways leading to cell death in irradiated sites. ${ }^{46,47}$ Following these processes, leucocytes roll to the damaged intestine in a short time for eliminating dead cells (Figure 2). ${ }^{48,49}$
Regarding the development of inflammation, current opinions believe that the molecular reactions in this process occur at sites extremely close to the vascular endothelium. ${ }^{50}$ Upon endothelial apoptosis, pro-inflammatory effectors will be secreted for the recruitment of leucocytes recruitment to injured sites. ${ }^{48,50}$ Herein, neutrophils are the first cells to adhere to endothelium and migrate to injured sites, where they eliminate dead cell debris for facilitating tissue repair. ${ }^{41,48,49,51}$ However, the irradiated epithelium always leads to a reduced barrier function. ${ }^{1}$ On this occasion, neutrophils also participate in eliminating large amounts of pathogens within the enteric cavity through secreting high levels of anti-pathogenic effectors, such as myeloperoxidase (MPO); ${ }^{52}$ this process will increase the oxidative stress within injured intestine and reduce tissue regeneration thereby (Figure 2). Meanwhile, upon exposure of injured tissues to pathogens, the cytotoxic $T$ lymphocytes will eliminate the cells infected by these foreign stimuli through secreting cytolytic substances, such as perforin and granzymes, and through Fas/Fas ligand binding-induced apoptosis (Figure 2). ${ }^{53,54}$ Thus, the presence of pathogens promotes inflammation and induces a switch from an innate immune response to an adaptive immune response, ${ }^{48,54}$ which has the inflammation extended in irradiated sites. 


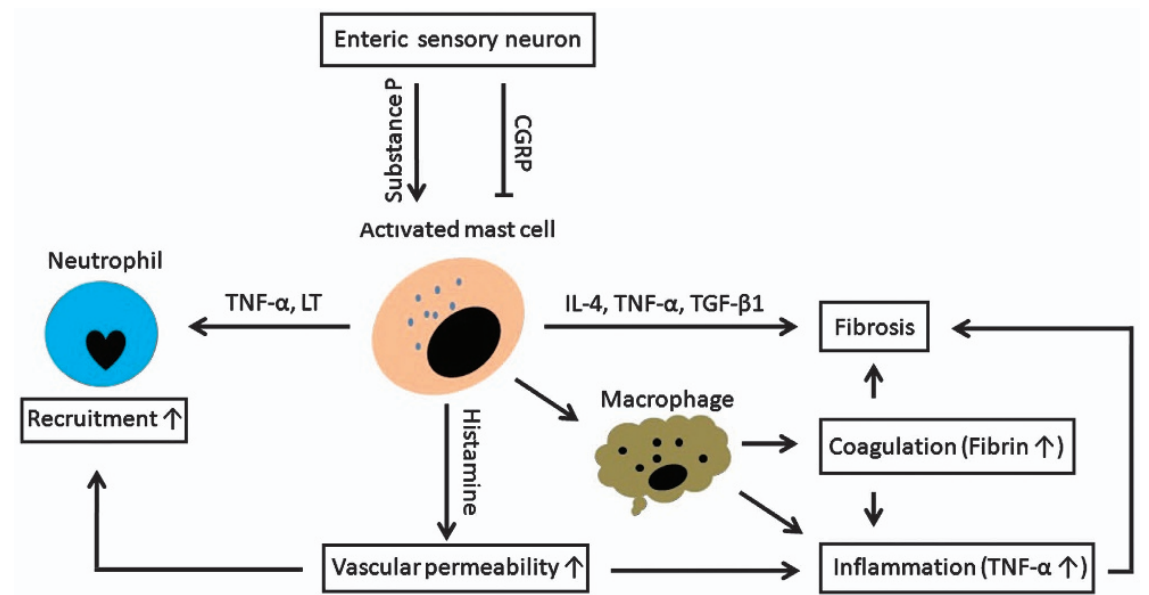

Figure 3 The contribution of neuroimmune interactions to RE development. Upon being irradiated, the mast cells will be activated, presenting the release of pro-inflammatory and pro-fibrotic effectors, including TNF- $\alpha$, histamine, LT, IL-4 and TGF- $\beta$ 1. These actions will be amplified by substance P, whereas be reversed by CGRP. LT, leukotriene; CGRP, calcitonin gene-related peptide

\begin{abstract}
Neuroimmune event: interactions between mast cells and enteric neurons. The neuroimmune interactions between enteric neurons and mast cells formulate a network for controlling intestinal responses to ionizing irradiation, presenting the lesions of mucositis and fibrosis. ${ }^{55}$ But the mast cells distinguish their contributions to the pathogenesis of RE. ${ }^{55}$ Upon being irradiated, the mast cells within intestinal mucosa will be activated, presenting the release of some effectors, such as TNF- $a$ and leukotriene (LT), for attracting neutrophils to clear bacteria-induced infection (Figure 3). ${ }^{55}$ Moreover, these activated mast cells will enhance TNF- $a$ secretion by macrophages as well as macrophage-mediated fibrin deposition for coagulation (Figure 3) ${ }^{55}$ But for the mast cells in connective tissue, their contribution to RE is secreting some pro-fibrotic effectors, such as TGF- $\beta 1$, IL-4 and TNF- $\alpha$ (Figure 3). ${ }^{55}$ Although the exact mechanism by which neuroimmune interactions regulate the development of $R E$ remains unknown, it is clear that the mediators from enteric sensory neurons, such as substance $\mathrm{P}$ and calcitonin generelated peptide (CGRP), are critical for regulating the activation of mast cells. Herein, substance $P$ is capable of amplifying the pro-inflammatory and pro-fibrotic responses of mast cells to ionizing irradiation through enhancing the secretions of histamine, TNF- $\alpha$ and TGF- $\beta 1$ by these cells, whereas the CGRP protects intestine against radiationinduced injuries (Figure 3 ) ${ }^{55}$ From this aspect, it is rational to propose that substance $\mathrm{P}$ is even important in deciding the severity of RE through activating mast cells.
\end{abstract}

Microbial event: dysbiosis post-irradiation. McLaughlin et al. ${ }^{56}$ reported that the germ-free mice present radiation resistance comparing with conventional mice, indicating a potential link between the microbiota and host response to ionizing irradiation. As we are aware, the healthy gut contains nearly 300-500 bacterial species. ${ }^{57}$ These commensal bacteria confer the intestine a barrier function, presenting persistent epithelial turnover and vigorous immunity. ${ }^{57}$ For example, the NF-KB signaling pathway in epithelial cells and some intestine-specific immune cells will be activated upon the interactions between their toll-like receptors and luminal bacteria, which stimulate the epithelial proliferation as well as lead to immune tolerance of intestine to foreign antigens. ${ }^{58}$ However, when the epithelium loses its integrity postirradiation, the commensal bacteria will transmigrate into intestinal tissue, functioning as bioterrorists for even triggering sepsis. ${ }^{57,58}$ In this context, dysbiosis commonly occurs. Manichanh et al..$^{59}$ reported that the bacterial constitution of feces is altered after the patients receiving pelvic radiotherapy, presenting the increased clusters of Bacilli and Actinobacteria, whereas decreasing in clostridial cluster. Besides, previous data indicated that the microbiota confer the intestinal endothelium and lymphocyts radiation sensitivity, which is linked to the suppression of fasting-induced adipose factor by luminal microbiota ${ }^{60}$ To a certain extent, this finding corresponds to that endothelial injuries are the primary lesions of RE. ${ }^{40}$ In current opinions, the interactions between the microbiota and host regulate the intestinal responses to ionizing irradiation, and not all intestinal bacteria promote pathogenesis of RE. ${ }^{57,58}$ For example, the microbiota can induce epithelial expression of nucleotidebinding oligomerization domain-containing protein 2 (NOD-2) against ischemia/reperfusion-induced hypoxic stress and autophagy, ${ }^{61}$ indicating the bacteriotherapy for RE is also promising. $^{62}$

Fibrotic event: fibrogenesis after tissue injuries. Radiation-induced injuries in epithelium and endothelium have a central role in initiating intestinal fibrosis, which can be promoted by the extended inflammation within injured sites. $^{24,25}$ Upon epithelial injuries, irradiated intestine will reduce its barrier functions. ${ }^{1}$ On this occasion, the innate immune cells, such as macrophages and dendritic cells (DCs), will be activated by pathogens in enteric cavity, leading to secretion of pro-inflammatory cytokines, such as TNF- $a$, IL-1, IL-4 and IL- $8 .{ }^{63}$ These cytokines activate some adaptive immune cells, such as Th2 and Th17 cell, which separately secrete $\mathrm{IL}-13$ and $\mathrm{IL}-17$ for promoting tissue remodeling (Figure 2). ${ }^{41,63}$ Upon endothelial injuries, the 
blood vessels will increase their permeability, enabling recruitment of pro-inflammatory cells to injured sites. ${ }^{41}$ Among these infiltrated cells, the monocyte-macrophage system is reported to facilitate fibrosis through secreting PDGF, CTGF and TGF- $\beta 1$, allowing for fibroblastmyofibroblast transition, myofibroblast proliferation and ECM deposition at injured sites (Figure 2). ${ }^{64,65}$

\section{Stem Cell-Based Regenerative Therapy for Rodent Models of RE}

In the past decade, extensive efforts have been made in stemcell based therapy for rodent models of RE (Table 1).

The therapeutic effects of MSCs on RE. To our knowledge, the first study was performed by Sémont et al. ${ }^{66}$ Their data showed that human MSCs exhibited potentials for maintaining the integrity of irradiated intestine. ${ }^{66}$ After MSC intervention, the irradiated mice survived longer than controls, and the epithelium showed hypertrophic villi, comprising increased numbers of proliferative cells and fewer apoptotic cells in the crypts. In addition, the newborn villus maintained its absorptive function via normal levels of $\mathrm{Na}^{+}-\mathrm{K}^{+}$-ATPase expression. ${ }^{67}$ Similarly, Kudo et al. ${ }^{68}$ reported that MSCs could extend the life span of irradiated mice, which was distinct from their previous data by using embryonic stem cells (ESCs) transplantation. ${ }^{69}$ Regarding the repair actions by MSCs, Saha et al. ${ }^{70}$ reported that MSCs could protect irradiated intestine by increasing serum levels of R-spondin1, KGF, IL-10 and PGE2, which function as effectors for promoting proliferation and inhibiting both apoptosis and inflammation within irradiated intestine. Besides, MSCs were capable of promoting epithelial regeneration using their secretion of IL-6. ${ }^{71}$ Moreover, the MSC-conditioned medium also exhibited the pro-regenerative potentials for irradiated epithelium. ${ }^{72}$ Besides, we found that MSC infusion could accelerate neovascularization within irradiated sites by triggering the intrinsic repair action of upregulated expressions of SDF-1, VEGF, basic FGF and Flk-1. ${ }^{73}$ Afterwards, by using a pig model of radiation proctitis, Linard et al. ${ }^{74}$ reported that repeated autologous transplantation of MSCs could counter act the inflammation in rectal mucosa by increasing host IL-10 production, and protect rectum against radiation-induced fibrosis by reducing local Col1a2/Col3a1 and TGF- $\beta /$ CTGF expression and altering the matrix metalloproteinase (MMP)-tissue inhibitor of metalloproteinase (TIMP) balance as well. Similarly, based on using a rat model of radiation proctitis, Bessout et al. ${ }^{75}$ reported that autologous transplantation of MSCs was capable of mitigating the aberrant inflammation in the colorectal mucosa by elevating the local levels of glucocorticoid, which would inhibit the proliferation and induce apoptosis in radiation-activated $\mathrm{T}$ cells. These preclinical studies indicate that MSC-based therapy is potent for repairing the lesions associated with RE. Especially for using heterogenic MSCs, the host repair can be triggered as well, attributing to the autocrine/paracrine actions achieved by MSCs.

The MSC-based gene therapy for RE. The chemotactic properties of MSCs enable themselves to be used as delivery vehicles for the targeted secretion of tissue repair factors at injured sites. Herein, several lines of evidence showed that radiation-induced upregulation in CXCL12 expression is important for the homing of MSCs to injured sites through the interaction between CXCR4 and CXCL12. ${ }^{76-78}$ For improving the homing efficacy of MSCs toward irradiated intestine, Zhang et al. ${ }^{79}$ established the MSCs, overexpressing CXCR4 gene, and found that the restoration of epithelial integrity was accelerated upon intervention by CXCR4 genemodified MSCs. In another study, Yang et al. ${ }^{80}$ reported that manganese superoxide dismutase (MSD) gene-modified MSCs were more effective than control MSCs in reducing mortality of irradiated mice, relieving gastrointestinal symptoms and restoring epithelial integrity with a spot of apoptotic cells in irradiated mice. Moreover, $\mathrm{Hu}$ et al. ${ }^{81}$ revealed that MSCs overexpressing Trx-1 gene were powerful in reducing oxidative stress in the irradiated intestine. Overall, the superior effectiveness of gene-modified MSCs over unmodified MSCs in healing RE can be attributed to the dual therapeutic effects of the high expression of ectopic genes and the intrinsic functions of MSCs.

\section{Putative Actions Involved in RE Resolution by MSC Infusion}

At present, the mechanisms involved in the repair of irradiated intestine by MSCs are still not fully investigated. But according to recent advances, we suggest several putative actions of RE management achieved by MSCs. In our opinion, the putative actions by which MSCs repair RE can be summarized as follows (Figure 4). Primarily, the engrafted MSCs induce infiltrated immune cells to switch from pro-inflammatory to antiinflammatory cytokine secretion, resulting in milieus that promote anti-inflammatory events. As a secondary effect, repair responses are boosted by systemic events, such as elevated levels of regenerative facilitators, despite the rapid disappearance of donor MSCs. ${ }^{82}$ Thus, benign cytokine milieus cause regeneration of the injured intestine to be accelerated.

Step 1: homing to injured sites. Homing of infused MSCs to injured sites can be regarded as a prerequisite. According to recent data, several events mediated this homing process, such as CXCR1/2-CXCL8, CXCR4-CXCL12, CX ${ }_{3}$ CR1fractalkine, CCR7-CCL21 and ICAM-1/VCAM-1. ${ }^{77,83-85}$ Upon these molecular bindings, MSCs first adhere to the endothelium, forming a defensive barrier against pathogens together with the pre-existing pericytes. ${ }^{86}$ The foreign MSCs then migrate to the laminar propria, where they perform proregenerative functions. ${ }^{87}$

Step 2: interacting with immune cells and bacteria. Cytokines secreted by both immune cells and MSCs mediate crosstalk among these cell types through regulatory feedback mechanisms, termed as 'Educational action' of MSCs (Figure 5). ${ }^{17}$ The engrafted MSCs will alter the inflammatory milieus through interacting with infiltrated immune cells via secretion central immune mediators, including IL-10, PGE2, iNOS, IDO and HLA-G5. ${ }^{17}$ For example, in a co-culturing system, BM-MSC increases the 


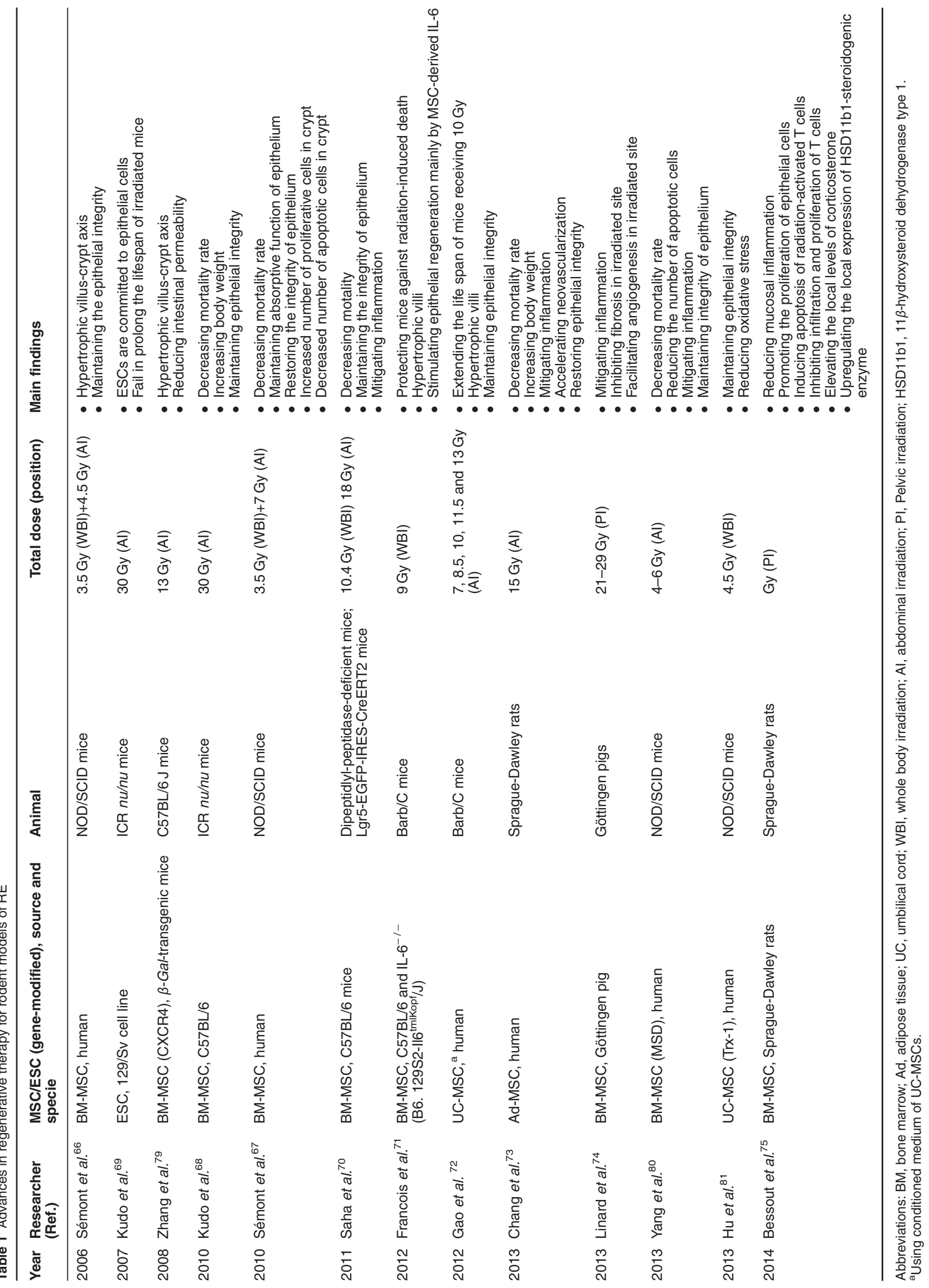


Step1: Homing to injured sites

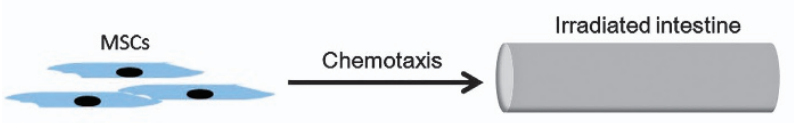

Step 2: Interacting with immune cells and bacteria

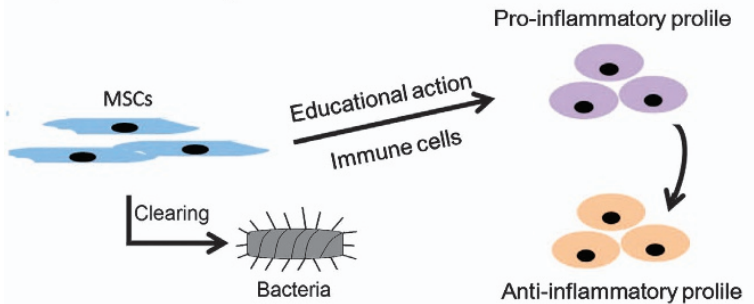

Step 3: Amplification of intrinsic repair

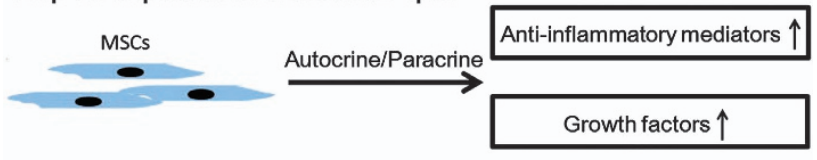

Step 4: Post-regeneration reversion of tissue homeostasis

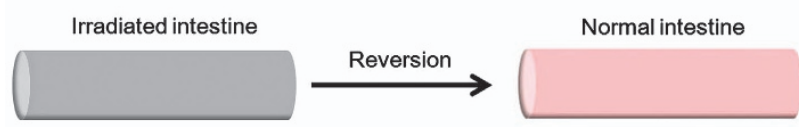

Figure 4 The putative actions by which MSCs repair radiation enteropathy. Four steps are involved in the processes of MSCs healing injuries in irradiated intestine, including cell-homing, interacting with immune cells, boosting intrinsic repair actions and reversing the homeostasis of injured tissue

IL-10 secretion and decreases the TNF- $a$ secretion in DCs; reduces IFN- $\gamma$ secretion in Th1 cells and natural killer (NK) cells, and increases IL-4 secretion in Th2 cells. ${ }^{88}$ Under the same conditions, macrophages increase IL-10 and IL-12p40 secretion, while reducing TNF- $a$, IFN- $\gamma$, IL- 6 and IL-12p70 secretion. ${ }^{89}$ These effects have also been observed in vivo: Németh et al. ${ }^{90}$ found that MSC infusion-induced elevation of host PGE2 has a central role in enhancing IL-10 synthesis by monocytes and macrophages from the lungs of septic mice, while reducing $\mathrm{IL}-12$ secretion from these immune cells. These events inhibited neutrophil infiltration and IL-12induced activations of both NK cells and cytotoxic T lymphocytes. ${ }^{90,91}$

In addition to the antagonistic effects of MSCs on immune cell pro-inflammatory profiles, the MSCs can inhibit the proliferation of effective $T$ lymphocytes through secreting iNOS or HLA-G5, inhibiting DC maturation using PGE2, and inhibiting NK-mediated cytolysis and NK proliferation using PGE2, HLA-G5 or IDO (Figure 5). ${ }^{92-94}$ In contrast to their antiproliferative effects on such immune cells, MSCs will stimulate proliferation of regulatory T cells (Tregs) via secreting HLA-G5 and PGE2 (Figure 5). ${ }^{94,95}$ Recent in vivo data also confirmed that MSC infusion can increase the Treg number in mice with colitis; this increase is dependent on MSCs migrating to the spleen and interacting with splenic $C D 11 b^{+}$innate immune cells. ${ }^{96,97}$ But for radiation proctitis, current opinion on whether IL-10 and/or Tregs participate in suppressing mucosal inflammation seems to be contradictive. A previous study found that the antagonistic effect of MSCs on the inflammation in colorectal mucosa of rat exhibited the IL-10/Treg-independent manner, which is opposite to the finding by using a pig model. ${ }^{74,75}$ In spite of similar strategies in establishing animal models of radiation proctitis and carrying out autologous transplantation, the mechanism by which MSCs mitigate intestinal inflammation probably varies among species. In addition, the following issues, including delivery times and doses of MSCs, appear to affect the host responses in clearing systemic or local inflammation.

As described above, neuroimmune interactions and dysbiosis contribute to the pathogenesis of RE. Fortunately, recent data suggested that MSCs antagonized the activation of mast cells by secreting PGE2 and TGF- $\beta 1$, leading to decreased degranulation, reduced ability of chemotaxis and reduced release of TNF- $a$ by mast cells (Figure 5).98,99 Moreover, accumulative evidence suggest that human MSCs are powerful in protecting against Gram-negative bacteria-induced sepsis, relying on their secretions of LL-37, IDO and heme oxygenase-1 ( $\mathrm{HO}-1)$, and strengthening the phagocytosis by neutrophils and macrophages as well (Figure 5). ${ }^{100-103}$

Step 3: amplification of intrinsic repair. To date, it is still difficult to define the extent to which allogenic/heterogenic MSCs contribute to tissue regeneration, because immune rejection driven by recipient $\mathrm{CD}^{+}$and/or $\mathrm{CD}^{+} \mathrm{T}$ lymphocytes and oxidative stress within injured areas were reported to limit viability of infused MSCs. ${ }^{82,104}$ But relatively few ectopic MSCs can lead to excellent therapeutic effects on injured host tissues that have a lost a large number of functional cells. A previous study reported that enhanced tissue repair achieved despite donor MSCs being rapidly eliminated after transplantation. ${ }^{105}$ From this point, we conclude that MSCs act as facilitators via triggering and boosting systemic repair responses. In spite of no consensus on whether the anti-inflammatory effect of MSCs on irradiated rectum of IL-10 and/or Treg involvment, reduced inflammation is always achieved after infusion of MSCs. ${ }^{74,75}$ Combining with the actions of MSCs in clearing bacteria and minimizing the activation of mast cells, benign milieus for tissue regeneration are established, which will be beneficial to attract host bone marrow progenitors for reconstructing the niches of CBC stem cells and building on vasculature. ${ }^{106,107}$ On this basis, by using the assistances from locally upregulated mitotic facilitators, ${ }^{70,83}$ re-epithlialization and angiogenesis/neovascularization in the injured intestine are accelerated thereby.

Step 4: post-regeneration reversion of tissue homeostasis. When the neo-formed epithelium or endothelium is restored to its normal size and structure, p53-mediated cellcycle arrest halts cell proliferation and prevents tissue hypertrophy. Levels of cytokine or hormone secretion are altered in the host tissue to maintain physiological epithelial homeostasis. ${ }^{108,109}$ This process provides an adequate blood supply to the gut, eliminates inflammation and prevents fibrosis from developing in the irradiated intestine. 


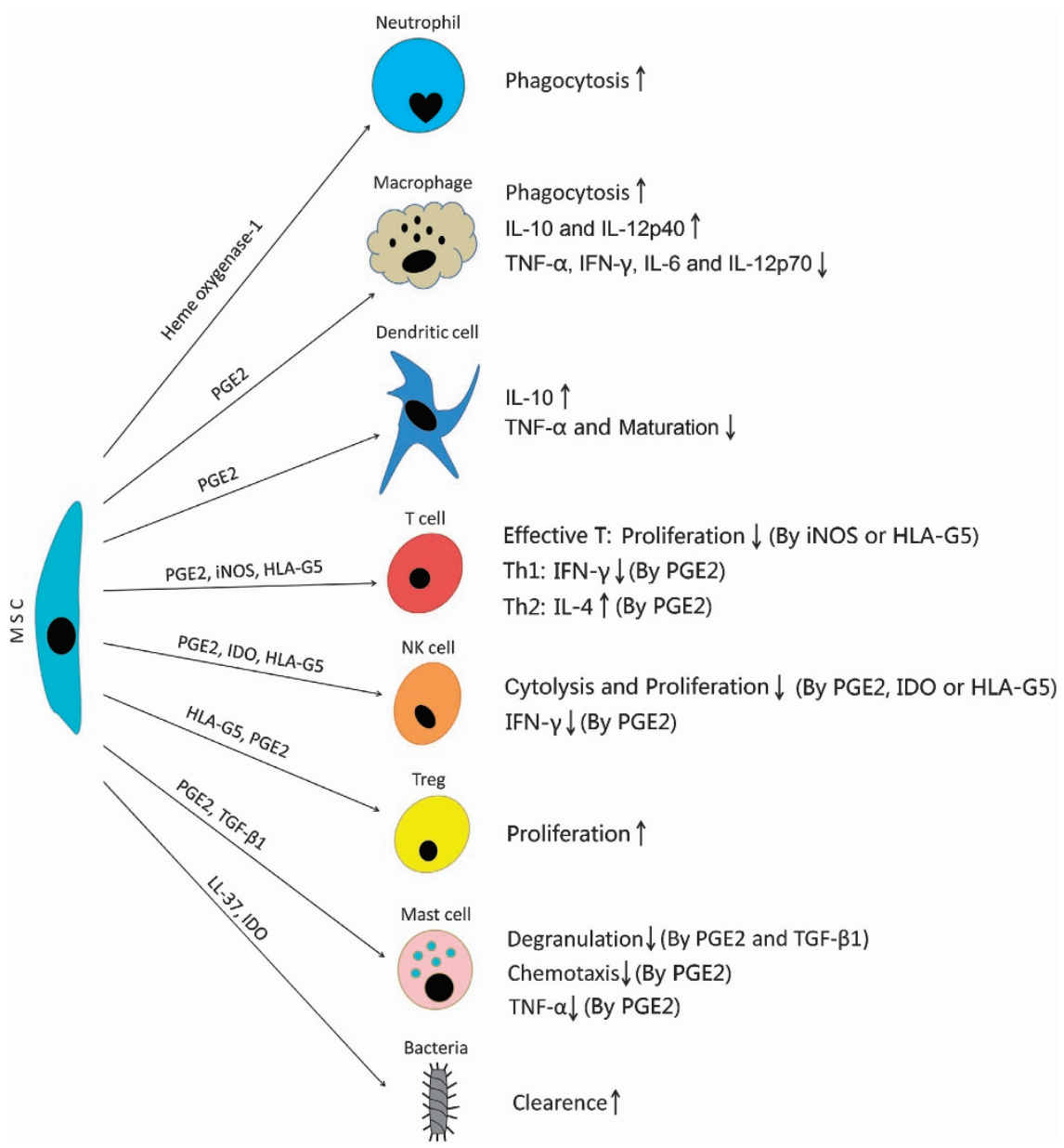

Figure 5 The interactions between MSCs and immune cells/Bacteria. Upon co-culturing with MSCs, the pro-inflammatory profiles of immune cells, including macrophages, dendritic cells, Teffector cells, NK cells and mast cells, will be altered into the anti-inflammatory ones. By contrast, the proliferation of Tregs will be promoted by MSCs. Besides, MSCs have the anti-bacterial potentials, and the phagocytosis by neutrophils and macrophages will be strengthened by MSCs

\section{MSC and Cancer: A Latent Factor Affecting Security of MSCs for RE}

The clinical responses of four Epinal patients to MSC-based therapy preliminarily revealed the specific roles of MSCs in treating pelvic radiotherapy-induced injuries in rectum and in bladder. ${ }^{6,23}$ Although no evidence indicating the relapses in their prostate cancers after MSC intervention, ${ }^{23}$ the debate over whether MSCs promote the growth and metastasis of cancer cells or initiate new cancers persists for a long time, because truth lies in that majority of RE patients are still cancer survivors. ${ }^{110}$

'Negative effects' of MSCs on tumor growth and their oncogenicity. Unrestricted cancer cell proliferation is largely driven by dysregulated growth signals originating from mutated genes. ${ }^{110}$ Some researchers believe that MSC-initiated immune suppression, immune cell dysfunction, cell division and angiogenesis could promote cancer progression. ${ }^{111,112}$ In addition, MSCs would undergo spontaneous malignant transformation during a culture period of 105 weeks. ${ }^{1{ }^{13-115}}$ Genomic instability, such as spontaneous p53 mutation in aged or in p21-deficient MSCs, was related to fibrosarcoma formation in vivo. ${ }^{114-117}$ By contrast, the risk of genetic mutations or cell aging could be minimized, if MSCs are cultured for less than 16 weeks. ${ }^{118,119}$

'Positive effects' of MSCs on tumor growth and their anticancer potential. Recent data also suggested that MSCs exhibited potentials for inhibiting tumor growth through arresting cell cycling and activating signaling pathways related to cell death (Table 2). ${ }^{120-133}$ For example, human adipose MSCs could inhibit tumor cell expansion via secreting Dickkopf-related protein 1, a Wnt signaling antagonist. ${ }^{134-136}$ Another anticancer activity of MSCs involved the blockade of PI3K/Akt signaling pathway, leading to increased levels of cell-death related molecules, while decreased levels of cell survival-related molecules (Table 2). ${ }^{121,133,137}$

In addition, MSC-based gene therapy for various solid tumors improves host anticancer responses through releasing the foreign gene-encoded proteins, such as iNOS, IL-2 and IL-12. ${ }^{138-140}$ Optimistically, some clinical trials for evaluating the specific potentials of MSCs on treating cancer and cancer regimen-related disorders are being carried out (ClinicalTrials. gov data). Relevant results will be referred for anticipating the potential risks related to MSC-based therapy. 


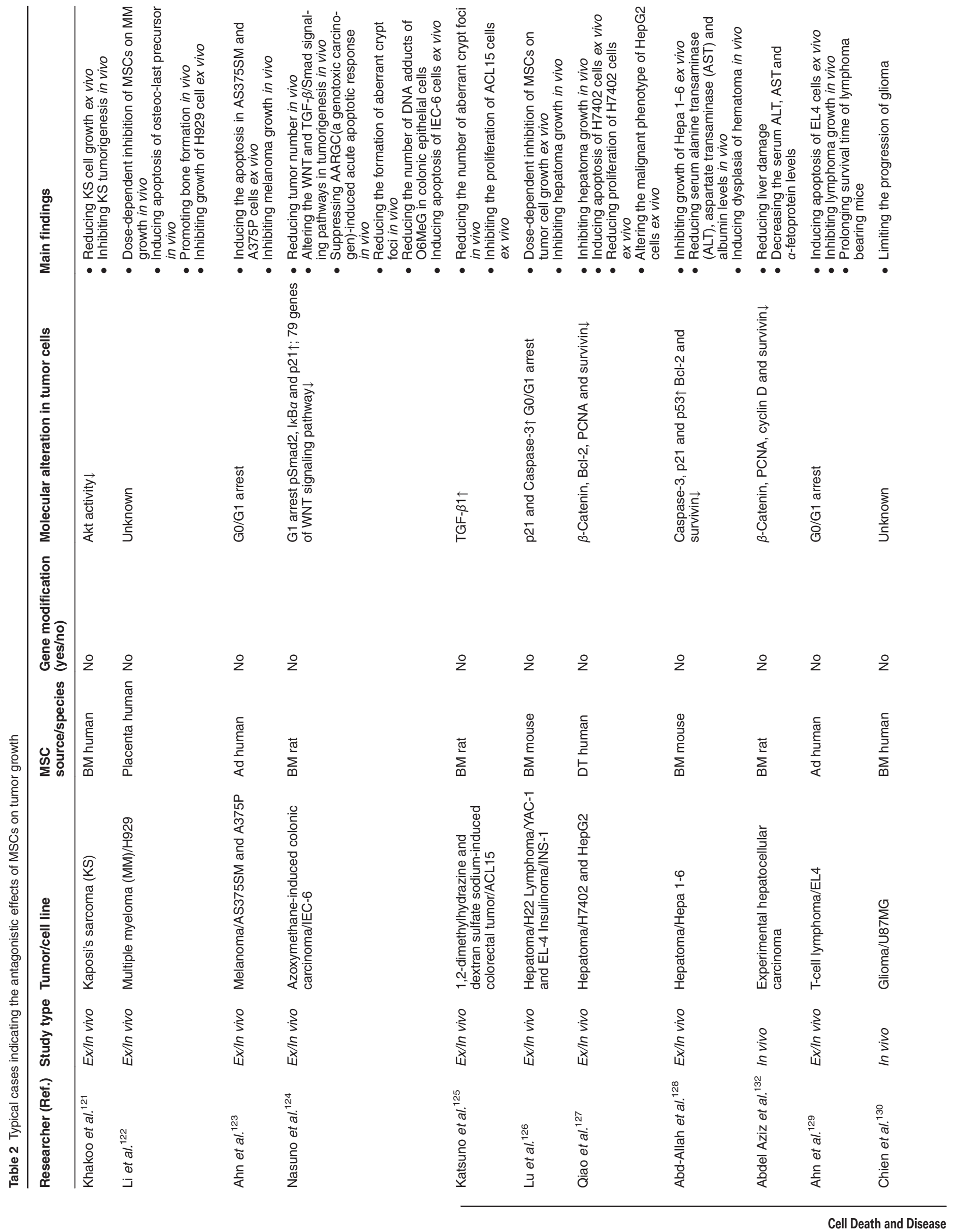




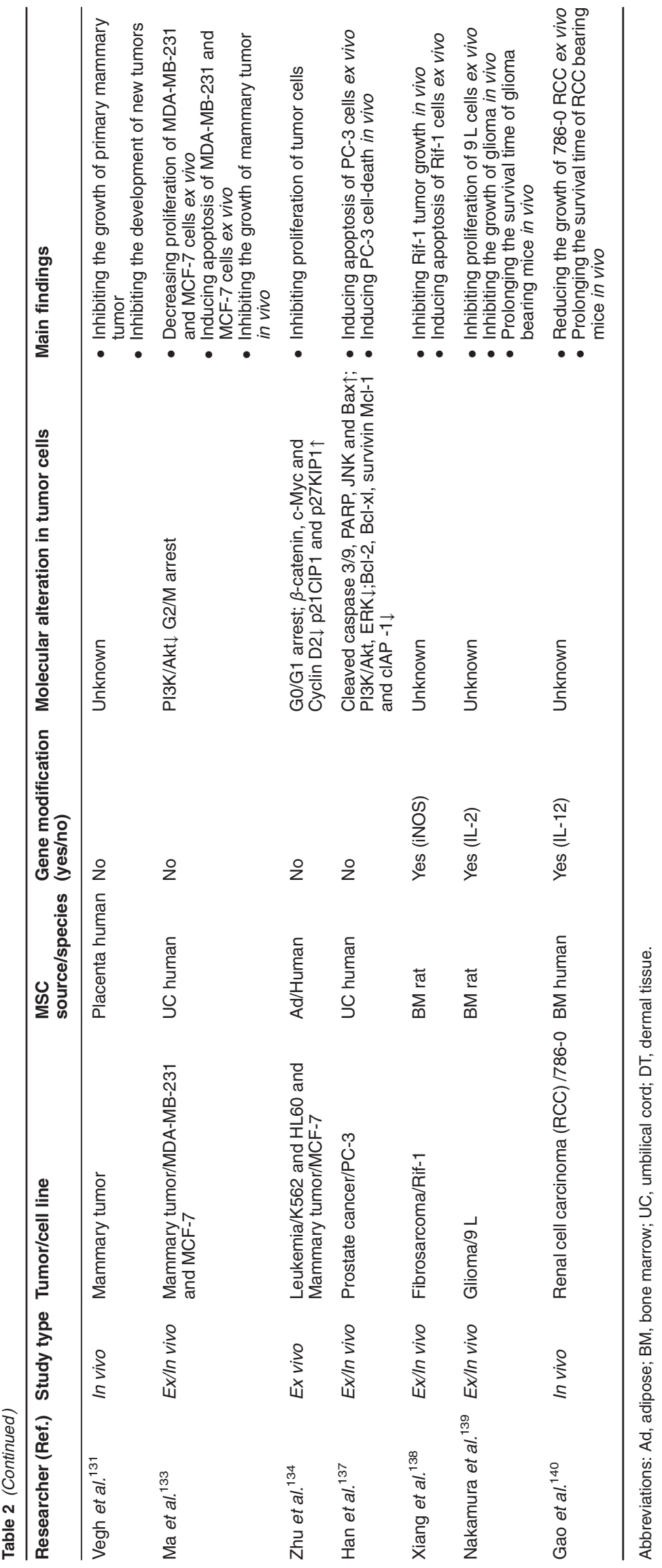




\section{Future Efforts into MSC-Based Therapy for RE Patients}

Because of the success in treating Epinal patients by using MSCs, a new protocol for treating late severe damages of abdominal radiotherapy has been performed in Epinal Medical Center since 2013. ${ }^{141}$ Certainly, the 'Epinal experiences' will deserve being referred worldwide in the future. If so, then MSC-based therapy is merely an attractive tool in managing RE patients. And clinical use of MSCs should focus on the following rules: (i) Ensuring the quality control of MSCs, including the processes for generating MSCs, identifying MSCs, detecting pathogens and endotoxin, and removing residual supplements. ${ }^{142} \mathrm{~A}$ detailed protocol for generating clinical grade human MSCs can be consulted, ${ }^{143}$ if using autologous MSCs. If using allogenic MSCs, then some FDAapproved products are available nowadays. But when allogenic MSCs are poorly tolerated, MSC exosomes are expected to become alternative candidates for managing RE. First, MSC exosomes show the potentials in mediating tissue regeneration because they contain a broad spectrum of bioactive substance. ${ }^{144}$ For example, the adenylate kinase and nucleoside-diphosphate kinase within exosomes are critical in increasing ATP production within injured cells. ${ }^{144}$ Additionally, CD73 molecules presenting in MSC exosomes are capable of hydrolyzing AMP into adenosine, an activator for cell survival by stimulating MAPK and PI3K/Akt signaling pathways. ${ }^{144}$ Moreover, MSC exosomes contain more than 200 immunomodulatory proteins, which confer the antiinflammatory capability on exosomes. ${ }^{144}$ Second, the MSC exosomes seem to be stable in vitro, because their integrities and sizes were seldom affected by repeated freezingthawing, ${ }^{145}$ allowing single extraction of exosomes for multiple administrations clinically. (ii) Formulating a protocol for MSC therapy for RE, including the delivery route of MSCs, timing and frequency of injection, the optimal dose and passage. ${ }^{146}$ (iii) Making countermeasure against possible complications or emergencies related to MSC infusion, such as fever, allergy or even shock. ${ }^{142,147}$ (iv) Establishing the criteria for evaluating the effectiveness achieved by MSC infusion in RE resolution, which somewhat guarantees the researchers avoid overstating the positive outcomes. ${ }^{148-150}$

\section{Conclusions}

Overall, data from preclinical study and Epinal case report highlight the essentiality of futuristic use of MSCs in RE management. MSC-based therapy is expected to have beneficial effects on the quality of life of RE patients.

\section{Conflict of Interest}

The authors declare no conflict of interest.

Acknowledgements. This study was funded by the National Natural Science Funds of China (Grant: 81372929).

1. Hauer-Jensen M, Denham JW, Andreyev HJ. Radiation enteropathy-pathogenesis, treatment and prevention. Nat Rev Gastroenterol Hepatol 2014; 11: 470-479.

2. Tucker SL, Thames HD, Michalski JM, Bosch WR, Mohan R, Winter K et al. Estimation of $\alpha$ l $\beta$ for late rectal toxicity based on RTOG 94-06. Int J Radiat Oncol Biol Phys 2011; 81: $600-605$.
3. Brenner DJ. Fractionation and late rectal toxicity. Int J Radiat Oncol Biol Phys 2004; 60: 1013-1015

4. Kennedy GD, Heise CP. Radiation colitis and proctitis. Clin Colon Rectal Surg 2007; 20: 64-72.

5. Andreyev HJ, Davidson SE, Gillespie C, Allum WH, Swarbrick E. Practice guidance on the management of acute gastrointestinal problems arising as a result of treatment for cancer. Gut 2012; 61: 179-192.

6. Chaple A, Francois S, Douay L, Benderitter M, Voswinkel J. New insights for pelvic radiation disease treatment: multipotent stromal cell is a promise mainstay treatment for the restoration of abdominopelvic severe chronic damages induced by radiotherapy. World $J$ Stem Cells 2013; 5: 106-111.

7. Gilbert JD, Byard RW. Fatal ischemic enteritis with hemorrhage-a late complication of treated Wilms tumor. J Forensic Sci 2013; 58: 234-236.

8. Sarin A, Safar B. Management of radiation proctitis. Gastroenterol Clin North Am 2013; 42: 913-925.

9. Spinelli A, Correale C, Szabo H, Montorsi M. Intestinal fibrosis in Crohn's disease: medical treatment or surgery? Curr Drug Targets 2010; 11: 242-248.

10. Gothard L, Cornes P, Brooker S, Earl J, Glees J, Hall E et al. Phase II study of vitamin E and pentoxifylline in patients with late side effects of pelvic radiotherapy. Radiother Oncol 2005; 75: 334-341.

11. Hamama S, Delanian S, Monceau V, Vozenin MC. Therapeutic management of intestinal firbosis induced by radiation therapy: from molecular profiling to new intervention strategies et vice et versa. Fibrogenesis Tissue Repair 2012; 5: S13.

12. Bourgier $C$, Haydont V, Milliat F, Francois A, Holler V, Lasser $P$ et al. Inhibition of Rho kinase modulates radiation induced fibrogenic phenotype in intestinal smooth muscle cells through alteration of the cytoskeleton and connective tissue growth factor expression. Gut 2005; 54: 336-343.

13. Haydont V, Bourgier C, Pocard M, Lusinchi A, Aigueperse $\mathrm{J}$, Mathé $\mathrm{D}$ et al. Pravastatin Inhibits the Rho/CCN2/extracellular matrix cascade in human fibrosis explants and improves radiation-induced intestinal firbosis in rats. Clin Cancer Res 2007; 13: $5331-5340$.

14. Wang J, Boerma M, Fu Q, Kulkarni A, Fink LM, Hauer-Jensen M. Simvastatin ameliorates radiation enteropathy development after localized, fractionated irradiation by a protein C-independent mechanism. Int J Radiat Oncol Biol Phys 2007; 68: 1483-1490.

15. Jiang $Y$, Jahagirdar $B N$, Reinhardt RL, Schwartz RE, Keene $C D$, Ortiz-Gonzalez $X R$ et al. Pluripotency of mesenchymal stem cells derived from adult marrow. Nature 2002; 418: $41-49$

16. Park BS, Kim WS, Choi JS, Kim HK, Won JH, Ohkubo F et al. Hair growth stimulated by conditioned medium of adipose-derived stem cells is enhanced by hypoxia: evidence of increased growth factor secretion. Biomed Res 2010; 31: 27-34.

17. Yagi $\mathrm{H}$, Soto-Gutierrez A, Parekkadan B, Kitagawa $\mathrm{Y}$, Tompkins RG, Kobayashi $\mathrm{N}$ et al. Mesenchymal stem cells: mechanisms of immunomodulation and homing. Cell Transplant 2010; 19: 667-679.

18. Singh S, Saraiva L, Elkinton PT, Friedland JS. Regulation of matrix metalloproteinase-1,-3 and -9 in Mycobaterium tuberculosis-dependent respiratory networks by the rapamycinsensitive PI3K/p70(S6K) cascade. FASEB J 2014; 28: 85-93.

19. Newell LF, Deans RJ, Maziarz RT. Adult adherent stromal cells in the management of graftversus-host disease. Expert Opin Biol Ther 2014; 14: 231-246.

20. Wang D, Li J, Zhang Y, Zhang M, Chen J, Li X et al. Umbilical cord mesenchymal stem cell transplantation in active and refractory systemic lupus erythematosus: a multicenter clinical study. Arthritis Res Ther 2014; 16: R79.

21. Koh YG, Choi YJ. Intrapatellar fat pad-derived mesenchymal stem cell therapy for knee osteoarthritis. Knee 2012; 19: 902-907.

22. Herreros MD, Garcia-Arranz M, Guadalajara H, De-La-Quintana P, Garcia-Olmo DFATT Collaborative Group, Autologous expanded adipose-derived stem cells for the treatment of complex cryptoglandular perianal fistulas: a phase III randomized clinical trial (FATT 1: fistula Advanced Therapy Trial 1) and long-term evaluation. Dis Colon Rectum 2012; 55: 762-772.

23. Voswinkel J, Francois S, Simon JM, Benderitter M, Gorin NC, Mohty M et al. Use of mesenchymal stem cells (MSCs) in chronic inflammatory fistulizing and fibrotic diseases: a comprehensive review. Clin Rev Allergy Immunol 2013; 45: 180-192.

24. Langberg CW, Sauer T, Reitan JB, Hauer-Jensen M. Relationship between intestinal fibrosis and histopathologic and morphometric changes in consequential and late radiation enteropathy. Acta Oncol 1996; 35: 81-87.

25. Latella G, Di Gregorio J, Flati V, Rieder F, Lawrence IC. Mechanisms of initiation and progression of intestinal fibrosis in IBD. Scand J Gastroenterol 2015; 50: 53-65.

26. Umar S. Intestinal stem cells. Curr Gastroenterol Rep 2010; 12: 340-348.

27. Sato T, Vries RG, Snippert HJ, van de Wetering M, Barker N, Stange DE et al. Single Lgr5 stem cells build crypt-villus structures in vitro without a mesenchymal niche. Nature 2009; 459: 262-265.

28. van der Flier LG, Clevers H. Stem cells, self-renewal, and differentiation in the intestinal epithelium. Annu Rev Physiol 2009; 71: 241-260.

29. Ishizuka S, Martin K, Booth C, Potten CS, de Murcia G, Bürkle A. Poly(ADP-ribose) polymerase- 1 is a survival factor for radiation-exposed intestinal epithelial stem cells in vivo. Nucleic Acids Res 2003; 31: 6198-6205.

30. Zhu Y, Huang YF, Kek C, Bulavin DV. Apoptosis differently affects lineage tracing of Lgr5 and Bmi1 intestinal stem cell populations. Cell Stem Cell 2013; 12: 298-303. 
31. Frankenberg-Schwager M, Gebauer A, Koppe C, Wolf H, Pralle E, Frankenberg D. Single-strand annealing, conservative homologous recombination, nonhomologous DNA end joining, and the cell cycle-dependent repair of DNA double-strand breaks induced by sparsely or densely ionizing radiation. Radiat Res 2009; 171: 265-273.

32. Schepers AG, Vries R, van den Born M, van de Wetering M, Clevers H. Lgr5 intestinal stem cells have high telomerase activity and randomly segregate their chromosomes. EMBO J 2011; 30: 1104-1109.

33. Metcalfe C, Kljavin NM, Ybarra R, de Sauvage FJ. Lgr5+ stem cells are indispensible for radiation-induced intestinal regeneration. Cell Stem Cell 2014; 14: 149-159.

34. Sangiorgi E, Capecchi MR. Bmi1 is expressed in vivo in intestinal stem cells. Nat Genet 2008; 40: 915-920.

35. Montgomery RK, Carlone DL, Richmond CA, Farilla L, Kranendonk ME, Henderson DE et al. Mouse telomerase reverse transcriptase (mTert) expression marks slowly cycling intestinal stem cells. Proc Natl Acad Sci USA 2011; 108: 179-184.

36. Sato T, van Es JH, Snippert HJ, Stange DE, Vries RG, van den Born M et al. Paneth cells constitute the niche for Lgr5 stem cells in intestinal crypts. Nature 2011; 469: 415-418.

37. Gilbert S, Nivarhi H, Mayhew CN, Lo YH, Noah TK, Vallance J et al. Activated STAT5 confers resistance to intestinal injury by increasing intestinal stem cell proliferation and regeneration. Stem Cell Reports 2015; 4: 209-225.

38. Ungvari Z, Podlusky A, Sosnowska D, Tucsek Z, Toth P, Deak F et al. lonizing radiation promotes the acquisition of a senescence-associated secretory phenotype and impairs angiogenic capacity in cerebromicrovascular endothelial cells: role of increased DNA damage and decreased DNA repair capacity in microvascular radiosensitivity. J Gerontol $A$ Biol Sci Med Sci 2013; 68: 1443-1457.

39. Abderrahmani R, Francois A, Buard V, Tarlet G, Blirando K, Hneino M et al. PAl-1-dependent endothelial cell death determines severity of radiation-induced intestinal injury. PLoS One 2012; 7: e35740.

40. Paris F, Fuks Z, Kang A, Capodieci P, Juan G, Ehleiter D et al. Endothelial apoptosis as the primary lesion initiating intestinal radiation damage in mice. Science 2001; 293: 293-297.

41. Wynn TA. Integrating mechanisms of pulmonary fibrosis. J Exp Med 2011; 208: $1339-1350$.

42. Giblin JP, Hewlett LJ, Hannah MJ. Basal secretion of von Willebrand factor from human endothelial cells. Blood 2008; 112: 957-964.

43. Kopaniak MM, Issekutz AC, Movat HZ. Kinetics of acute inflammation induced by $\mathrm{E}$ coli in rabbits. Quantitation of blood flow, enchanced vascular permeability, hemorrhage, and leukocyte accumulation. Am J Pathol 1980; 98: 485-498.

44. Nikjoo H, O'Neill P, Terrissol M, Goodhead DT. Modelling of radiation-induced DNA damage: the early physical and chemical event. Int J Radiat Biol 1994; 66: 453-457.

45. Hill S, Van Remmen H. Mitochondrial stress signaling in longevity: A new role for mitochondrial function in aging. Redox Biol 2014; 2: 936-944.

46. Martindale JL, Holbrook NJ. Cellular response to oxidative stress: signaling for suicide and survival. J Cell Physiol 2002; 192: 1-15.

47. Almeida AS, Figueiredo-Pereira C, Vieira HL. Carbon monoxide and mitochondriamodulation of cell metabolism, redox response and cell death. Front Physiol 2015; 6: 33 .

48. Mittal M, Siddigui MR, Tran K, Reddy SP, Malik AB. Reactive oxygen species in inflammatory and tissue injury. Antioxid Redox Signal 2014; 20: 1126-1167.

49. Johnson LB, Riaz AA, Adawi D, Wittgren L, Bäck S, Thornberg C et al. Radiation enteropathy and leucocyte-endothelial cell reactions in a refined small bowel model. $B M C$ Surg 2004; 4 : 10

50. Rao RM, Yang L, Garcia-Cardena G, Luscinskas FW. Endothelial-dependent mechanisms of leukocyte recruitment to the vascular wall. Circ Res 2007; 101: 234-247.

51. Kolaczkowska E, Kubes P. Neutrophil recruitment and function in health and inflammation. Nat Rev Immunol 2013; 13: 159-175.

52. Reumaux D, de Boer M, Meijer AB, Duthilleul P, Roos D. Expression of myeloperoxidase (MPO) by neutrophils is necessary for their activation by anti-neutrophil cytoplasm autoantibodies (ANCA) against MPO. J Leukoc Biol 2003; 73: 841-849.

53. Wonderlich J, Shearer G, Livingstone A, Brooks A. Induction and measurement of cytotoxic T lymphocyte activity. Curr Protoc Immunol 2006; Chapter 3: Unit 3.11.

54. Kugelberg E. Pattern recognition receptors: curbing gut inflammation. Nat Rev Immunol 2014; 14: 583.

55. Wang J, Hauer-Jensen M. Neuroimmune interactions: potential target for mitigating or treating intestinal radiation injury. $\mathrm{Br} J$ Radiol 2007; 1: S41-S48.

56. McLaughlin MM, Dacquisto MP, Jacobus DP, Horowitz RE. Effects of the germfree state on responses of mice to whole-body irradiation. Radiat Res 1964; 23: 333-349.

57. Ferreira MR, Muls A, Dearnaley DP, Andreyev HJ. Microbiota and radiation-induced bowel toxicity: lesions from inflammatory bowel disease for the oncologist. Lancet Oncol 2014; 15: e139-e147.

58. Packey $\mathrm{CD}$, Ciorba MA. Microbial influences on the small intestinal response to radiation injury. Curr Opin Gastroenterol 2010; 26: 88-94.

59. Manichanh C, Varela E, Martinez C, Antolin M, Liopis M, Doré J et al. The gut microbiota predispose to the pathophysiology of acute postradiotherapy diarrhea. Am J Gastroenterol 2008; 103: 1754-1761.

60. Crawford PA, Gordon Jl. Microbial regulation of intestinal radiosensitivity. Proc Natl Acad Sci USA 2005; 102: 13254-13259.

61. Perez-Chanona E, Mühlbauer M, Jobin C. The microbiota protects against ischemia/ reperfusion-induced intestinal injury through nucleotide-binding oligomerization domaincontaining protein 2 (NOD2) signaling. Am J Pathol 2014; 184: 2965-2975.
62. Ciorba MA, Stenson WF. Probiotic therapy in radiation-induced intestinal injury and repair. Ann NY Acad Sci 2009; 1165: 190-194.

63. Lawrance IC, Rogler G, Bamias G, Breynaert C, Florholmen J, Pellino G et al. Cellular and molecular mediators of intestinal fibrosis. $J$ Crohns Colitis 2014; e-pub ahead of print 8 October 2014; doi: 10.1016/j.crohns.2014.09.008.

64. Haydont V, Vozenin-Brotons MC. Maintenance of radiation-induced intestinal fibrosis: cellular and molecular features. World J Gastroenterol 2007; 13: 2675-2683.

65. Yarnold J, Brotons MC. Pathogenetic mechanisms in radiation fibrosis. Radiother Oncol 2010; 97: 149-161.

66. Sémont A, Francois S, Mouiseddine M, Francois A, Saché A, Frick J et al. Mesenchymal stem cells increase self-renewal of small intestinal epithelium and accelerate structural recovery after radiation injury. Adv Exp Med Biol 2006; 585: 19-30.

67. Sémont A, Mouiseddine M, Francois A, Demarguay C, Mathieu N, Chapel A et al. Mesenchymal stem cells improve small intestinal integrity though regulation of endogenous epithelial cell homeostasis. Cell Death Differ 2010; 17: 952-961.

68. Kudo K, Liu Y, Takahashi K, Tarusawa K, Osanai M, Hu DL et al. Transplantation of mesenchymal stem cells to prevent radiation-induced intestinal injury in mice. J Radiat Res 2010; 51: 73-79.

69. Kudo K, Abe Y, Hu DL, Kijima H, Nakane A. Colonization and differentiation of transplanted embryonic stem cells in the irradiated intestine of mice. Tohoku J Exp Med 2007; 212 143-150.

70. Saha S, Bhanja P, Kabarriti R, Liu L, Alfieri AA, Guha C. Bone marrow stromal cell transplantation mitigates radiation-induced gastrointestinal syndrome in mice. PLoS One 2011; 6: e24072.

71. Francois M, Birman E, Forner KA, Gaboury L, Gallipeau J. Adoptive transfer of mesenchymal stromal cells accelerates intestinal epithelium recovery of irradiated mice in an interleukin-6-dependent manner. Cytotherapy 2012; 14: 1164-1170.

72. Gao Z, Zhang Q, Han Y, Cheng X, Lu Y, Fan L et al. Mesenchymal stromal cell-conditioned medium prevents radiation-induced small intestine injury in mice. Cytotherapy 2012; 14 267-273.

73. Chang P, Qu Y, Liu Y, Cui S, Zhu D, Wang H et al. Multi-therapeutic effects of human adipose-derived mesenchymal stem cells on radiation-induced intestinal injury. Cell Death Dis 2013; 4: e685.

74. Linard C, Busson E, Holler V, Strup-Perrot C, Lacave-Lapalun JV, Lhomme B et al. Repeated autologous bone marrow-derived mesenchymal stem cell injections improve radiation-induced proctitis in pigs. Stem Cells Transl Med 2013; 2: 916-927.

75. Bessout R, Sémont A, Demarguay C, Charcosset A, Benderitter M, Mathieu N. Mesenchymal stem cell therapy induces glucocorticoid synthesis in colonic mucosa and suppresses radiation-activated T cells: new insights into MSC immunomodulation. Mucosal Immunol 2014; 7: 656-669.

76. Zong ZW, Cheng TM, Su YP, Ran XZ, Shen Y, Li N et al. Recruitment of transplanted dermal multipotent stem cells to sites of injury in rats with combined radiation and wound injury by interaction of SDF-1 and CXCR4. Radiat Res 2008; 170: 444-450.

77. Ji JF, He BP, Dheen ST, Tay SS. Interactions of chemokines and chemokine receptors mediate the migration of mesenchymal stem cells to the impaired site in the brain after hypoglossal never injury. Stem Cells 2004; 22: 415-427.

78. Francois S, Bensidhoum M, Moureseddine M, Mazurier C, Allenet B, Sémont A et al. Local irradiation not only induces homing of human mesenchymal stem cells at exposed sites but promotes their widespread engraftment to multiple organs: a study of their quantitative distribution after irradiation damage. Stem Cells 2006; 24: 1020-1029.

79. Zhang J, Gong JF, Zhang W, Zhu WM, Li JS. Effects of transplated bone marrow mesenchymal stem cells on the irradiated intestine of mice. J Biomed Sci 2008; 15: $585-594$

80. Yang C, Chen HX, Zhou Y, Liu MX, Wang JX, Ren SP et al. Manganese superoxide dismutase gene therapy protects against irradiation-induced intestinal injury. Curr Gene Ther 2013; 13: 305-314.

81. Hu J, Yang Z, Wang J, Tang Y, Liu H, Zhang B et al. Infusion of Trx-1-overexpressing huc MSC prolongs the survival of acutely irradiated NOD/SCID mice by decreasing excessive inflammatory injury. PLoS One 2013; 8: e78227.

82. Zangi L, Margalit R, Reich-Zeliger S, Bachar-Lustig E, Beilhack A, Negrin R et al. Direct imaging of immune rejection and memory induction by allogeneic mesenchymal stromal cells. Stem Cells 2009; 27: 2865-2874.

83. Hu C, Yong X, Li C, Lü M, Liu D, Chen L et al. CXCL12/CXCR4 axis promotes mesenchymal stem cell mobilization to burn wounds and contributes to wound repair. J Surg Res 2013; 183: 427-434.

84. Ren G, Zhao X, Zhang L, Zhang J, L'Huillier A, Ling W et al. Inflammatory cytokine-induced intercellular adhesion molecule-1 and vascular cell adhesion molecule-1 in mesenchymal stem cells are critical for immunosuppression. J Immunol 2010; 184: 2321-2328.

85. Ringe J, Strassburg S, Neumann K, Endres M, Notter M, Burmester GR et al. Towards in situ tissue repair: human mesenchymal stem cells express chemokine receptors CXCR1, CXCR2 and CCR2, and migrate upon stimulation with CXCL8 but not CCL2. J Cell Biochem 2007; 101: 135-146.

86. Paguet-Fifield S, Schlüter H, Li A, Aitken T, Gangatirkar P, Blashki D et al. A role for pericytes as microenvironmental regulators of human skin tissue regeneration. $J$ Clin Invest 2009; 119: 2795-2806.

87. Linero I, Chaparro O. Paracrine effect of mesenchymal stem cells from human adipose tissue in bone regeneration. PLoS One 2014; 9: e107001. 
88. Aggarwal S, Pittenger MF. Human mesenchymal stem cells modulate allogeneic immune cell responses. Blood 2005; 105: 1815-1822.

89. Maggini J, Mirkin G, Bognanni I, Holmberg J, Piazzón IM, Nepomnaschy I et al. Mouse bone marrow-derived mesenchymal stromal cells turn activated macrophages into a regulatory-like profile. PLoS One 2010; 5: e9252.

90. Németh K, Leelahavanichkul A, Yuen PS, Mayer B, Parmelee A, Doi K et al. Bone marrow stromal cells attenuate sepsis via prostaglandin $E(2)$-dependent reprogramming of host macrophages to increase their interleukin-10 production. Nat Med 2009; 15 42-49.

91. Pils MC, Pisano F, Fasnacht N, Heinrich JM, Groebe L, Schippers A et al. Monocytes/ macrophages and/or neutrophils are the target of IL-10 in the LPS endotoxemia model. Eur $\mathrm{J}$ Immunol 2010; 40: 443-448.

92. Spaggiari GM, Abdelrazik H, Becchetti F, Moretta L. MSCs inhibit monocyte-derived DC maturation and function by selectively interfering with the generation of immature DCs: central role of MSC-derived prostaglandin E2. Blood 2009; 113: 6576-6583.

93. Spaggiari GM, Capobianco A, Abdelrazik H, Becchetti F, Mingari MC, Moretta L. Mesenchymal stem cells inhibit natural killer-cell proliferation, cytotoxicity, and cytokine production: role of indoleamine 2,3-dioxygenase and prostaglandin E2. Blood 2008; 111 : 1327-1333.

94. Selmani Z, Naji A, Zidi I, Favier B, Gaiffe E, Borg C et al. Human leukocyte antigen-G5 secretion by human mesenchymal stem cells is required to suppress $T$ lymphocyte and natural killer function and to induce CD4+CD25highFOXP3+ regulatory T cells. Stem Cells 2008; 26: 212-222

95. Hsu WT, Lin CH, Chiang BL, Jui HY, Wu KK, Lee CM. Prostaglandin E2 potentiates mesenchymal stem cell-induced IL-10+IFN- $\gamma+\mathrm{CD} 4+$ regulatory T cells to control transplan arteriosclerosis. J Immunol 2013; 190: 2372-2380.

96. Gonzalez-Rey E, Anderson P, González MA, Rico L, Büscher D, Delgado M. Human adult stem cells derived from adipose tissue protect against experimental colitis and sepsis. Gut 2009; 58: 929-939.

97. Parekkadan B, Upadhyay R, Dunham J, Iwamoto Y, Mizoguchi E, Mizoguchi A et al. Bone marrow stromal cell transplants prevent experimental enterocolitis and require host CD11b+ splenocytes. Gastroenterology 2011; 140: 966-975.

98. Brown JM, Nemeth K, Kushnir-Sukhov NM, Metcalfe DD, Mezey E. Bone marrow stromal cells inhibit mast cell function via a COX2-dependent mechanism. Clin Exp Allergy 2011; 41: $526-534$.

99. Kim HS, Yun JW, Shin TH, Lee SH, Lee BC, Yu KR. Human umbilical cord blood mesenchymal stem cell-derived PGE2 and TGF- $\beta 1$ Alleviate atopic dermatitis by reducing mast cell degranulation. Stem Cells 2015; 33: 1254-1266.

100. Lombard E, van der Poll T, DelaRosa O, Dalemans W. Mesenchymal stem cells as a therapeutic tool to treat sepsis. World J Stem Cells 2015; 7: 368-379.

101. Meisel R, Brockers S, Heseler K, Degistirici O, Bülle $\mathrm{H}$, Woite $\mathrm{C}$ et al. Human but not murine multipotent mesenchymal stromal cells exhibit broad-spectrum antimicrobial effector function mediated by indoleamine 2,3-dioxygenase. Leukemia 2011; 25 648-654.

102. Krasnodembskaya A, Samarani G, Song Y, Zhou H, Su X, Lee JW et al. Human mesenchymal stem cells reduce mortality and bacteremia in gram-negative sepsis in mice in part by enhancing the phagocytic activity of blood monocytes. Am J Physiol Lung Cell Mol Physiol 2012; 302: L1003-L1013.

103. Krasnodembskaya A, Song Y, Fang X, Gupta N, Serikov V, Lee JW et al. Antibacterial effect of human mesenchymal stem cells is mediated in part from secretion of the antimicrobial peptide LL-37. Stem Cells 2010; 28: 2229-2238.

104. Chang W, Song BW, Moon JY, Cha MJ, Ham O, Lee SY et al. Anti-death strategies against oxidative stress in grafted mesenchymal stem cells. Histol Histopathol 2013; 28 : 1529-1536.

105. Lange C, Brunswig-Spickenheier B, Cappallo-Obermann H, Eggert K, Gehling UM, Rudolph $\mathrm{C}$ et al. Radiation rescue: mesenchymal stromal cells protect from lethal irradiation. PLoS One 2011; 6: e14486.

106. Brittan M, Chance V, Elia G, Poulsom R, Alison MR, MacDonald TT et al. A regenerative role for bone marrow following experimental colitis: contribution to neovasculogenesis and myofibroblasts. Gastroenterology 2005; 128: 1984-1995.

107. Okamoto R, Yajima T, Yamazaki M, Kanai T, Mukai M, Okamoto S et al. Damaged epithelial regenerated by bone marrow-derived cells in the human gastrointestinal tract. Nat Med 2002; 8: 1011-1017.

108. Guan A, Gong H, Ye Y, Jia J, Zhang G, Li B et al. Regulation of p53 by jagged 1 contributes to angiotensin II-induced impairment of myocardial angiogenesis. PLoS One 2013; 8 : e76529.

109. Demidov ON, Timofeev O, Lwin HN, Kek C, Appella E, Bulavin DV. Wip1 phosphatase regulates p53-dependent apoptosis of stem cells and tumorigenesis in the mouse intestine. Cell Stem Cell 2007; 1: 180-190.

110. John S. Mesenchymal stem cells in cancer. Stem Cell Rev 2008; 4: 119-124.

111. Kuhn NZ, Tuan RS. Regulation of stemness and stem cell niche of mesenchymal stem cells: implications in tumorigenesis and metastasis. J Cell Physiol 2010; 222: 268-277.

112. Han Z, Jing $Y$, Zhang S, Liu $Y$, Shi $Y$, Wei $L$. The role of immunesuppression of mesenchymal stem cells in tissue repair and tumor growth. Cell Biosci 2012; 2: 8.

113. Røsland GV, Svendsen A, Torsvik A, Sobala E, Mc Cormack E, Immervoll H et al. Long-term cultures of bone marrow-derived human mesenchymal stem cells frequently undergo spontaneous malignant transformation. Cancer Res 2009; 69: 5331-5339.
114. Burns JS, Abdallah BM, Guldberg P, Rygaard J, Schrøder HD, Kassem M. Tumorigenic heterogeneity in cancer stem cells evolved from long-term cultures of telomeraseimmortalized human mesenchymal stem cells. Cancer Res 2005; 65: 3126-3135.

115. Rubio D, Garcia-Castro J, Martín MC, de la Fuente R, Cigudosa JC, Lloyd AC et al. Spontaneous human adult stem cell transformation. Cancer Res 2005; 65: 3035-3039.

116. Li H, Fan X, Kovi RC, Jo Y, Moguin B, Konz R et al. Spontaneous expression of embryonic factors and p53 point mutations in aged mesenchymal stem cells: a model of age-related tumorigenesis in mice. Cancer Res 2007; 67: 10889-10898.

117. Rodriguez R, Rubio R, Masip M, Catalina $P$, Nieto $A$, de la Cueva $T$ et al. Loss of p53 induces tumorigenesis in p21-deficient mesenchymal stem cells. Neoplasia 2009; 11: 397-407.

118. Bernardo ME, Zaffaroni N, Novara F, Cometa AM, Avanzini MA, Moretta A et al. Human bone marrow derived mesenchymal stem cells do not undergo transformation after long-term in vitro culture and do not exhibit telomere maintenance mechanisms. Cancer Res 2007; 67: 9142-9149.

119. Choumerianou DM, Dimitriou H, Perdikogianni C, Martimianaki G, Riminucci M, Kalmanti M. Study of oncogenic transformation in ex vivo expanded mesenchymal cells, from paediatric bone marrow. Cell Prolif 2008; 41: 909-922.

120. Zimmerlin L, Park TS, Zambidis ET, Donnenberg VS, Donnenberg AD. Mesenchymal stem cell secretome and regenerative therapy after cancer. Biochimie 2013; 95: 2235-2245.

121. Khakoo AY, Pati S, Anderson SA, Reid W, Elshal MF, Rovira II et al. Human mesenchymal stem cells exert potent antitumorigenic effects in a model of Kaposi's sarcoma. J Exp Med 2006; 203: 1235-1247.

122. Li X, Ling W, Pennisi A, Wang $Y$, Khan S, Heidaran $M$ et al. Human placenta-derived adherent cells prevent bone loss, stimulate bone formation, and suppress growth of multiple myeloma in bone. Stem Cells 2011; 29: 263-273.

123. Ahn JO, Coh YR, Lee HW, Shin IS, Kang SK, Youn HY. Human adipose tissue-derived mesenchymal stem cells inhibit melanoma growth in vitro and in vivo. Anticancer Res 2015; 35: 159-168.

124. Nasuno $M$, Arimura $Y$, Nagaishi $K$, Isshiki $H$, Onodera $K$, Nakagaki $S$ et al. Mesenchymal stem cells cancel azoxymethane-induced tumor initiation. Stem Cells 2014; 32: 913-925.

125. Katsuno T, Ochi M, Tominaga K, Tanaka F, Sogawa M, Tanigawa T et al. Mesenchymal stem cells administrated in the early phase of tumorigenesis inhibit colorectal tumor development in rats. J Clin Biochem Nutr 2013; 53: 170-175.

126. Lu YR, Yuan Y, Wang XJ, Wei LL, Chen YN, Cong $C$ et al. The growth inhibitory effect of mesenchymal stem cells on tumor cells in vitro and in vivo. Cancer Biol Ther 2008; 7 : 245-251.

127. Qiao L, Xu Z, Zhao T, Zhao Z, Shi M, Zhao RC et al. Suppression of tumorigenesis by human mesenchymal stem cells in a hepatoma model. Cell Res 2008; 18: 500-507.

128. Abd-Allah SH, Shalaby SM, El-Shai AS, Elkader EA, Hussein S, Emam E et al. Effect of bone marrow-derived mesenchymal stromal cells on hepatoma. Cytotherapy 2014; 16: 1197-1206.

129. Ahn JO, Chae JS, Coh YR, Jung WS, Lee HW, Shin IS et al. Human adipose tissue-derived mesenchymal stem cells inhibit T-cell lymphoma growth in vitro and in vivo. Anticancer Res 2014; 34: 4839-4847.

130. Chien LY, Hsiao JK, Hsu SC, Yao M, Lu CW, Liu HM et al. In vivo magnetic resonance imaging of cell tropism, trafficking mechanism, and therapeutic impact of human mesenchymal stem cells in a murine glioma model. Biomaterials 2011; 32: 3275-3284.

131. Vegh I, Grau M, Gracia M, Grande J, de la Torre P, Flores Al. Decidua mesenchymal stem cells migrated toward mammary tumors in vitro and in vivo affecting tumor growth and tumor development. Cancer Gene Ther 2013; 20: 8-16.

132. Abdel aziz MT, El Asmar MF, Atta HM, Mahfouz S, Fouad HH, Roshdy NK et al. Efficacy of mesenchymal stem cells in suppression of hepatocarcinorigenesis in rats: possible role of Wnt signaling. J Exp Clin Cancer Res 2011; 30: 49.

133. Ma Y, Hao X, Zhang S, Zhang J. The in vitro and in vivo effects of human umbilical cord mesenchymal stem cells on the growth of breast cancer cells. Breast Cancer Res Treat 2012; 133: 473-485

134. Zhu Y, Sun Z, Han Q, Liao L, Wang J, Bian $C$ et al. Human mesenchymal stem cells inhibit cancer cell proliferation by secreting DKK-1. Leukemia 2009; 23: 925-933.

135. Lee RH, Kim B, Choi I, Kim H, Choi HS, Suh K et al. Characterization and expression analysis of mesenchymal stem cells from human bone marrow and adipose tissue. Cell Physiol Biochem 2004; 14: 311-324.

136. Fodde R, Brabletz T. Wnt/beta-catenin signaling in cancer stemness and malignant behavior. Curr Opin Cell Biol 2007; 19: 150-158.

137. Han I, Yun M, Kim EO, Kim B, Jung MH, Kim SH. Umbilical cord tissue-derived mesenchymal stem cells induce aoptosis in $\mathrm{PC}-3$ prostate cancer cells through activation of JNK and downregulation of PI3KJAkt signaling. Stem Cell Res Ther 2014; 5 : 54

138. Xiang J, Tang J, Song C, Yang Z, Hirst DG, Zheng QJ et al. Mesenchymal stem cells as a gene therapy carrier for treatment of fibrosarcoma. Cytotherapy 2009; 11: 516-526.

139. Nakamura K, Ito Y, Kawano Y, Kurozumi K, Kobune M, Tsuda H et al. Antitumor effect of genetically engineered mesenchymal stem cells in a rat glioma model. Gene Ther 2004; 11: 1155-1164.

140. Gao $P$, Ding Q, Wu Z, Jiang $H$, Fang Z. Therapeutic potential of human mesenchymal stem cells producing IL-12 in a mouse xenograft model of renal cell carcinoma. Cancer Lett 2010; 290: $157-166$. 
141. Chapel A, Francois S, Douay L, Benderitter M, Voswinkel J. Fifteen years of preclinical and clinical experiences about biotherapy treatment of lesions induced by accidental irradiation and radiotherapy. World J Stem Cells 2013; 5: 68-72.

142. Bernardo ME, Fibbe WE. Safety and efficacy of mesenchymal stromal cell therapy in autoimmune disorders. Ann NY Acad Sci 2012; 1266: 107-117.

143. Robey PG, Kuznetsov SA, Ren J, Klein HG, Sabatino M, Stroncek DF. Generation of clinical grade human bone marrow stromal cells for use in bone regeneration. Bone 2015; 70: 87-92.

144. Lai RC, Yeo RW, Lim SK. Mesenchymal stem cell exosomes. Semin Cell Dev Biol 2015; 40 82-88.

145. Sokolova V, Ludwig AK, Hornung S, Rotan O, Horn PA, Epple M et al. Characterisation of exosomes derived from human cells by nanoparticle tracking analysis and scanning electron microscopy. Colloids Surf B Biointerfaces 2011; 87: 146-150.

146. Berardis S, Dwisthi Sattwika P, Najimi M, Sokal EM. Use of mesenchymal stem cells to treat liver fibrosis: Current situation and future prospects. World J Gastroenterol 2015; 21: 742-758.

147. Ohmori K, Masuda K, DeBoer DJ, Sakaguchi M, Tsujimoto H. Immunoblot analysis for lgEreactive components of fetal calf serum in dogs that developed allergic reactions after nonrabies vaccination. Vet Immunol Immunopathol 2007; 115: 166-171.
148. Abbott A. Leaked files slam stem-cell therapy. Nature 2014; 505: 139-140.

149. Salem HK, Thiemermann C. Mesenchymal stromal cells: current understanding and clinical status. Stem Cells 2010; 28: 585-596.

150. Lodi D, lannitti T, Palmieri B. Stem cells in clinical practice: applications and warnings. $J$ Exp Clin Cancer Res 2011; 30: 9.

(c) (i) Cell Death and Disease is an open-access journal published by Nature Publishing Group. This work is licensed under a Creative Commons Attribution 4.0 International License. The images or other third party material in this article are included in the article's Creative Commons license, unless indicated otherwise in the credit line; if the material is not included under the Creative Commons license, users will need to obtain permission from the license holder to reproduce the material. To view a copy of this license, visit http://creativecommons.org/licenses/by/4.0/ 